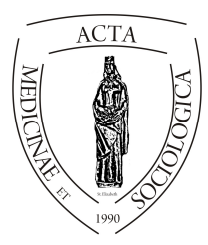

Acta Medicinae et

Sociologica (2019)

UNIVERSITY OF

DEBRECEN

Vol. 10. No. 29. (115-130)

FACULTY OF

HEALTH

doi:

NYÍREGYHÁZA

\title{
Telepi kapcsolatok
}

\section{Huszti Éva}

főiskolai docens. Debreceni Egyetem Egészségügyi Kar, 4400 Nyíregyháza, Sóstói u. 2-4.

INFO

Huszti Éva
huszti.eva@foh.unideb.hu

Keywords

contact network, confidential relationship, friendship, weak tie

kapcsolathálózat, bizalmas kapcsolatok, barátság,

gyenge kötések
Kulcsszavak

\section{ABSTRACT}

Abstract. Relationships in settlements. This study describes some features of the ego-centric contact network of people living in settlements based on the research from early 2019 done in two settlements in Nyíregyháza. Regarding strong ties, we examine confidential network, changes in the number of friends then we examine weak ties, too. This is a descriptive writing that presents the examined dimensions through socio-demographic variables like gender, age and education.

Absztrakt. A tanulmányban a 2019 elején, Nyíregyháza két
lakótelepén végzett kutatás eredményei alapján részletezzük a
telepeken élők egocentrikus kapcsolathálózatának néhány
jellemzőjét. Az erős kötések közül vizsgáljuk a bizalmas
kapcsolathálózatot, illetve a barátok számának alakulását,
majd áttekintjük a gyenge kötéseket is. A tanulmány alapve-
tően leíró, a vizsgált dimenziókat olyan szocio-demográfiai
változók mentén mutatjuk be, mint a megkérdezett neme, kora
és iskolai végzettsége.

Ez a tanulmány a TOP-6.9.1-16-NY1-2017-00001 azonosító számú

"Közösen a kiútért" címü projekt támogatásával készült. 


\section{Bevezetés}

A Nyíregyháza életminőségét vizsgáló, 2008-ban kezdődött háztartás panel kutatásba már a kezdezektől bekerült a társas kapcsolatok, mint az életminőséget meghatározó dimenzió részletes vizsgálata. Ennek alapját a Rahman modell (Rahman et al. 2005) adta, mely a következő 8 vizsgálati területet tartalmazza: 1. Családi, baráti viszonyok, 2. Érzelmi jólét, 3. Egészség, 4. Anyagi jólét, 5. A lokális közösséghez tartozás érzése, 6. Munka és aktivitás, 7. Személyes biztonság, 8. A környezet minősége. Ebben az első és az ötödik témakör is a társas kapcsolatoknak az életminőségben betöltött szerepét mutatja (Nyíregyháza Életminősége 2008, 2010, 2012, 2015; Fábián és mtsai, 2018)

Jelen kutatás a város két olyan lakótelepén élő felnőtt népesség életminőségét vizsgálja, mely sok szempontból eltér az átlagtól. Városi szinten ezen a két telepen a legrosszabbak a különböző szociális mutatók, amely jellemzően az alacsony iskolázottság, gazdasági aktivitás és jövedelmi helyzet vonatkozásában érhetők tetten.

Ahhoz, hogy az elemzett minta helyzetét, társas kapcsolatrendszerét jobban érzékeljük, röviden bemutatjuk a két lakótelepet. A Huszár lakótelep, mely a nagyobbik telep a kettő közül, az 1850-es éveket követően illeszkedett be Nyíregyháza városszerkezetébe, elsősorban lovassági - honvédségi laktanyaként funkcionált. A lakótelep egészen 1957-ig a honvédség tulajdonát képezte. Az 1960-as évek városrendezési, lakótelep-építési hulláma következtében kicserélődött a telep lakossága. A tehetős katonai és hivatali elit helyére jellemzően a városba költöző romák telepedtek be, amely folyamat tartósnak bizonyult. Jelenleg a lakóépületek többsége olcsó bérleti díjú, komfortnélküli, félkomfortos és komfortos önkormányzati tulajdonú szociális bérlakás. A telep szegregált helyzetét területi sajátosságai is érzékeltetik. A vasút leválasztja a lakótelepet a város főbb részeiről, a legrövidebb úton gyalog lehet csak megközelíteni a szomszédos, modernebb városrészt. Iskolázottság tekintetében a lakosság csaknem kétharmadának legfeljebb általános iskolai végzettsége van, amely jellemzően korlátozza a foglalkoztatási lehetőségeiket, amely negatív hatással van az életminőségük alakulására. A lakótelepen a közszolgáltatásokhoz való hozzáférés jónak mondható, hiszen a gyermekek számára bölcsőde, óvoda és felmenő rendszerben bővülő általános iskola áll rendelkezésre. Emellett lehetőség van a városban müködő, körzetes oktatási, nevelési intézményekbe is járni. Helyben elérhető család- és gyermekjóléti szolgáltatás, idősek nappali ellátása és alternatív napközbeni ellátás. A városrészben élők számára folyamatos természetbeni támogatásokat nyújtanak a különböző szociális, egészségügyi, egyházi és civil szervezetek.

A Keleti lakótelep elhelyezkedése szerencsésebb, kevésbé izolált a Huszártelephez képest. A terület a belvárostól mintegy 1,5 km-re, az Orosi út és a Kállói út között található, amely korábban a város határa volt. Idővel, a város terjeszkedését követően, a körülötte történt fejlesztések ellenére, megmaradt a szegregált jellege. A telep föutak melletti elhelyezkedésének köszönhetően a lakosok közszolgáltatásokhoz való hozzáférése kedvezőbb, a buszközlekedés rendszeres és gyakori, a belváros kerékpárúton is megközelíthető. A Keleti lakótelepen a lakóingatlanok komfortnélküliek, csak elektromos közmücsatlakozással rendelkeznek, müszaki állapotuk rendkívül elavult, felújításuk gazdaságtalan lehet. A telepet körülvevő utak állapota jó, a házsorok között vi- 
szont problémás a közlekedés, komoly gondot jelent a csapadékvíz elvezetése. Iskolázottság tekintetében szintén jelentős hasonlóság mutatkozik a nagyobb teleppel, hiszen itt is a lakosság csaknem kétharmadának legfeljebb általános iskolai végzettsége van, amely ugyancsak korlátozza a foglalkoztatási lehetőségeiket és életminőségük alakulását. (Balogh, 2019) Ezt bizonyítja az is, hogy bár sok vállalkozás található a környéken, mégis a „szomszédban” müködő NYÍRVV Nonprofit Kft. a legjelentősebb foglalkoztató a közfoglalkoztatáson keresztül. A közszolgáltatásokhoz való hozzáférés szintén jónak mondható, a belváros és az Örökösföld közelsége miatt több nevelési, oktatási intézmény elérhető. Helyben elérhető család- és gyermekjóléti szolgáltatás, idősek nappali ellátása és alternatív napközbeni ellátás. Háziorvosi ellátás elérése a belvárosban lehetséges, viszont a szakrendelök és a sürgősségi betegellátás néhány percre található. A védőnők jelenléte ugyancsak aktív a telepen.

\section{Anyag és módszer}

A kutatás során 271 fó válaszolt a kérdezőbiztosok által feltett kérdésekre a két telepen: Huszár lakótelep (74\%), Keleti lakótelep (26\%) (Bővebben lásd: Takács, Huszti, 2019). A válaszadók 69\%-a nő, átlagéletkoruk 43,6 év (Huszár lakótelep: 43,6 év, Keleti lakótelep 43,1 év). A válaszadók jellemzően alacsony iskolai végzettségüek. 59\%-uk magyarnak, 41\%-uk pedig romának/cigánynak vallja magát. A Huszár lakótelepen élö megkérdezettek 35\%-a, míg a Keleti lakótelepen élő megkérdezettek 57\%-a vallja magát romának/cigánynak. A kapcsolatban élők aránya átlagosan $60 \%$, a Huszár lakótelepen $57 \%$, a Keletin pedig 63\%. A háztartásokban élök létszáma a két telepen együtt 4,3 fö, de ebben jelentős eltérés van telepenként: a Huszár lakótelepen 3,8 fö/háztartás, míg a Keleti lakótelepen 4,6 fö/háztartás (Fábián, Takács, 2019). (1. táblázat)

\begin{tabular}{|l|r|c|c|c|}
\hline & & $\begin{array}{c}\text { Huszár } \\
\text { lakótelep } \\
(\mathbf{\%})\end{array}$ & $\begin{array}{c}\text { Keleti } \\
\text { lakótelep } \\
(\mathbf{\%})\end{array}$ & $\begin{array}{c}\text { Teljes telepi } \\
\text { minta } \\
(\mathbf{\%})\end{array}$ \\
\hline Nem & Férfi & 30 & 34 & 31 \\
& Nö & 70 & 66 & 69 \\
\hline Korcsoportok & $18-39$ évesek & 45 & 38 & 43 \\
& $40-59$ évesek & 40 & 47 & 42 \\
& $60+$ & 15 & 15 & 15 \\
\hline Iskolai végzettség & Max.8 általános & 73 & 83 & 76 \\
& Szakmunkás & 22 & 16 & 20 \\
& Érettségi + & 5 & 0 & 4 \\
\hline \multicolumn{2}{|l|}{ Kapcsolatban élók aránya } & 57 & 63 & 60 \\
(házastárs/élettárs) & & 3,8 fó & 4,6 fó & 4,3 fó \\
\hline \multicolumn{2}{|l|}{ Háztartás átlagos létszáma } & & \\
\hline
\end{tabular}

Forrás: Roma lakótelepen élők életminösége, 2019

1. táblázat A két vizsgált telep szocio-demográfiai jellemzői ( $\mathrm{N}=271)$ 


\section{Módszer}

A vizsgált minta kapcsolathálózatát három fő dimenzió mentén vizsgáltuk:

1. Az erős kötések (Granovetter, 1982) közül a bizalmas kapcsolatokat mértük az országos mérésekhez hasonlóan a következő névgenerátor (Fischer-McCallister, 1978) típusú kérdéssel: „, A legtöbb ember egy-egy fontos dolgot idönként megbeszél másokkal. Ha mondjuk az elmúlt egy évre gondol: kik azok az emberek, akikkel Ön a fontosabb dolgait, problémáit megbeszélte (pl. személyes problémák, családi ügyek, munkával kapcsolatos dolgok, stb.)”. A megnevezett személyekröl, illetve a válaszadó és a megnevezett közti kapcsolat néhány jellemzőjéről úgynevezett névinterpretáló kérdésekkel tájékozódtunk: a megnevezett személy neme, kora, iskolai végzettsége, a kapcsolat típusa, az ismerettség időtartama, milyen messze lakik, milyen támogatást nyújt a megkérdezettnek, tartozik-e kisebbséghez.

2. A barátok számát ugyancsak az országos és a nyíregyházi kutatásban is használt kérdéssel mértük: „Hány barátja van Önnek?”

3. A gyenge kötéseket (Granovetter, 1982) a legelterjedtebb módszer, a különféle foglalkozásokat tartalmazó ún. pozíció generátor (Lin-Dumin, 1986) technikával mértük: „A következökben felolvasok néhány foglalkozást. Kérem, mondja meg mindegyikröl, hogy személyesen ismer-e ilyen foglalkozású embereket. Ezek az emberek lehetnek az Ön rokonai, barátai, ismerösei. Ha több ugyanolyan foglalkozású embert is ismer, most gondoljon arra, aki leghamarabb eszébe jut közülük!" Az általában használatos kérdések mellett a kutatásban használt kérdőív tartalmazott névinterpretáló kérdéseket a foglalkozások kapcsán felidézett személyekre vonatkozóan, így vizsgálható a gyenge kötések néhány olyan paramétere is, melyek hasznosak lehetnek a társadalmi integráció szempontjából.

\section{Eredmények}

\section{Bizalmasok a kapcsolathálózatban}

A bizalmas kapcsolatok átlagos száma a megkérdezettek körében 1,48 volt. A Huszár lakótelepieknek átlagosan 1,27, míg a Keleti lakótelepen élőknek 2,1 bizalmasa volt. A bizalmasok átlagos száma között tehát szignifikáns különbség van attól függően, hogy melyik telepen él a megkérdezett $(\mathrm{p}=0,000)$. Az országos kutatás eredményei szerint, ahol egyébként maximum öt személyt jelölhettek, az átlag 2,19 volt (Albert, Dávid, 2016). Az általunk vizsgált telepeken, föleg a Huszár lakótelepen alacsonyabb a bizalmas kapcsolatok átlagos száma. A válaszadók 14\%-a nem tudott egyetlen bizalmas kapcsolatot sem megnevezni a kérdés kapcsán. A Huszár lakótelepi válaszadók 13\%-ának, míg a Keleti lakótelepi válaszadók 17\%-ának nincs bizalmasa, ami magas aránynak tekinthető, mivel az országos adatfelvételben a megkérdezettek 6,5\%-a nem tudott megnevezni egyetlen bizalmast sem.

$\mathrm{Az}$ adatok alapján tehát úgy tűnik, hogy a Huszár lakótelepen van néhány „,bizalmas-gazdag”, akinek akár tíz bizalmasa is van, de a válaszadók átlagosan keve- 
sebb bizalmast tudtak megnevezni, mint a Keleti lakótelepi válaszadók, ahol a bizalmasok átlagos száma magasabb. (2. táblázat)

\begin{tabular}{|r|r|c|c|c|c|}
\hline & & $\begin{array}{c}\text { Huszár lakóte- } \\
\text { lep }\end{array}$ & $\begin{array}{c}\text { Keleti } \\
\text { lakótelep }\end{array}$ & $\begin{array}{c}\text { Teljes } \\
\text { telepi } \\
\text { minta }\end{array}$ & $\begin{array}{c}\text { Országos } \\
\text { minta* } \\
\mathbf{( 2 0 1 5 )}\end{array}$ \\
\hline $\begin{array}{c}\text { Bizalmasok } \\
\text { száma }\end{array}$ & $\begin{array}{r}\text { Átlag } \\
\text { Min }\end{array}$ & 1,27 & 2,1 & 1,48 & 2,19 \\
& Max & 10 & 0 & 0 & 0 \\
Szórás & 1,06 & 6 & 10 & 5 \\
\hline \multicolumn{2}{r|}{ Férfi } & 1,1 & 1,54 & 1,25 & 1,31 \\
\hline Nó & 1,3 & 2,2 & 1,3 & 2,15 \\
& $18-39$ évesek & 1,3 & 2,4 & 1,5 & 2,22 \\
\hline 40-59 évesek & 1,1 & 2 & 1,4 & 2,4 \\
$60+$ & 1,4 & 2,1 & 1,6 & 1,9 \\
\hline Max. 8 osztály & 1,3 & 2,1 & 1,5 & 1,9 \\
Szakmunkás & 1 & 2,1 & 1,3 & 2 \\
Érettségi + & 1,2 & - & 1,2 & 2,3 \\
\hline
\end{tabular}

Forrás: Roma lakótelepen élök életminösége, 2019

*Integrációs és dezintegrációs folyamatok a magyar társadalomban címü OTKA kutatás adatfelvétele

2. táblázat A bizalmasok száma a vizsgált telepeken és országosan, szocio-demográfiai jellemzők szerinti bontásban (átlag)

A bizalmasok száma és a megkérdezettek neme, kora és iskolai végzettsége között kis eltéréseket láthatunk, ezek nem szignifikánsak. Ha a telepeket külön vizsgáljuk, akkor a különbségek jobban érzékelhetők: a vizsgált szociodemográfiai változók mentén rendre magasabb a Keleti lakótelepen élök bizalmas kapcsolatainak a száma. A telepek közötti eltérés szignifikáns $(\mathrm{p}=0,000)$. Az országos adatokhoz hasonlítva megállapítható, hogy minden vizsgált korcsoportban, illetve az iskolai végzettségek esetén is alacsonyabb a Huszár lakótelepen élők bizalmas kapcsolatainak a száma.

A bizalmasokra vonatkozó kérdés során említett kapcsolatok 57\%-a nő, az említett személyek átlagéletkora 39,8 (Min.2 Max.94 Std.dev.13,508). A megnevezett személyek iskolai végzettsége, hasonlóan a megkérdezettekhez, leginkább maximum nyolc általános (67\%). 24\% a szakmunkás végzettségü alterek és $9 \%$ az ettől magasabb iskolai végzettséggel rendelkezők aránya. Ezek alapján elmondható, hogy a bizalmas kapcsolatokat tekintve a megkérdezettek kapcsolatrendszere homofíl, azaz a saját magukhoz hasonló szociodemográfiai ismérvekkel jellemezhető mások találhatók meg benne.

A bizalmas kapcsolatokat vizsgáló kérdés során a kutatásban a következő típusokat soroluk fel: $1=$ házastárs/élettárs $2=$ szülö, 3=gyermek, 4=testvér, 5=egyéb rokon, 6=régebbi szomszéd, 7=jelenlegi szomszéd, 8=régebbi osztálytárs, 9=jelenlegi osztálytárs, $10=$ régebbi tanár, $11=$ jelenlegi tanár, $12=$ korábbi munkatárs, $13=$ jelenlegi munkatárs, $14=$ közeli barát, $15=$ családsegítő $16=$ védőnő $17=$ orvos $18=$ egyéb. A kapcsolatok típusait tekintve alapvetően két csoportba sorolhatók: 1) családi, rokoni kapcsolatok (1-5 kód) illetve 2) nem rokoni kapcsolatok (6-18 kód). A bizalmasként említett kapcsolatok jelentős része a családi, rokoni kapcsolatokat jelenti, hiszen a 
felsorolt személyek több mint háromnegyede (78,5\%) közeli vagy távolabbi családtag és alacsony $(21,5 \%)$ az úgynevezett gyenge kötések aránya. A makrotársadalmi integrációhoz szükséges gyenge típusú kapcsolatok közül leggyakrabban a közeli barátot, és a szomszédokat (jelenlegi vagy régebbi) említették a megkérdezettek a bizalmasaik között. Fontos megjegyezni, hogy a megkérdezettek egyike sem jelölt meg olyan bizalmast, aki az oktatáshoz kapcsolható (jelenlegi osztálytárs, régebbi vagy jelenlegi tanár), illetve az egészségügyhöz sorolható személyek (orvos, védőnő) sem kerültek említésre a bizalmasok között.

Az 1. ábrán láthatjuk, hogy a bizalmasként említett kapcsolatok típusa hogyan alakul egyrészt az országos adatokhoz viszonyítva, másrészt pedig a két telep között. Míg közeli családi kapcsolatokat lényegesen nagyobb arányban említettek a telepi válaszadók, mint országosan, addig a barátok említése a bizalmasok között jelentősen elmarad az országos arányoktól ( $8 \%$ vs. 58\%). A munkatársak, mint bizalmas kapcsolatok említése is ritkább a telepiek körében. A szomszédok gyakrabban szerepelnek a telepiek bizalmas kapcsolathálózatában, mint az országos mérésnél (10\% vs. 5\%).

A Keleti lakótelepi válaszadók nagyobb arányban említik házastársukat / élettársukat bizalmasként, valamint szüleiket, gyermekeiket és testvéreiket is. A gyermekek bizalmasként való említése a Keleti lakótelepiek körében kiemelkedik (44\%-uk említett gyermeket bizalmasként). Az egyéb rokonok említése is a Keleti lakótelepiek körében volt gyakoribb. A közeli barát említése mindkét lakótelepen jelentősen elmarad az országostól. A munkatársak (korábbi, jelenlegi), szomszédok, és egyéb nem rokonok aránya is magasabb volt a Keleti lakótelepen élök körében.

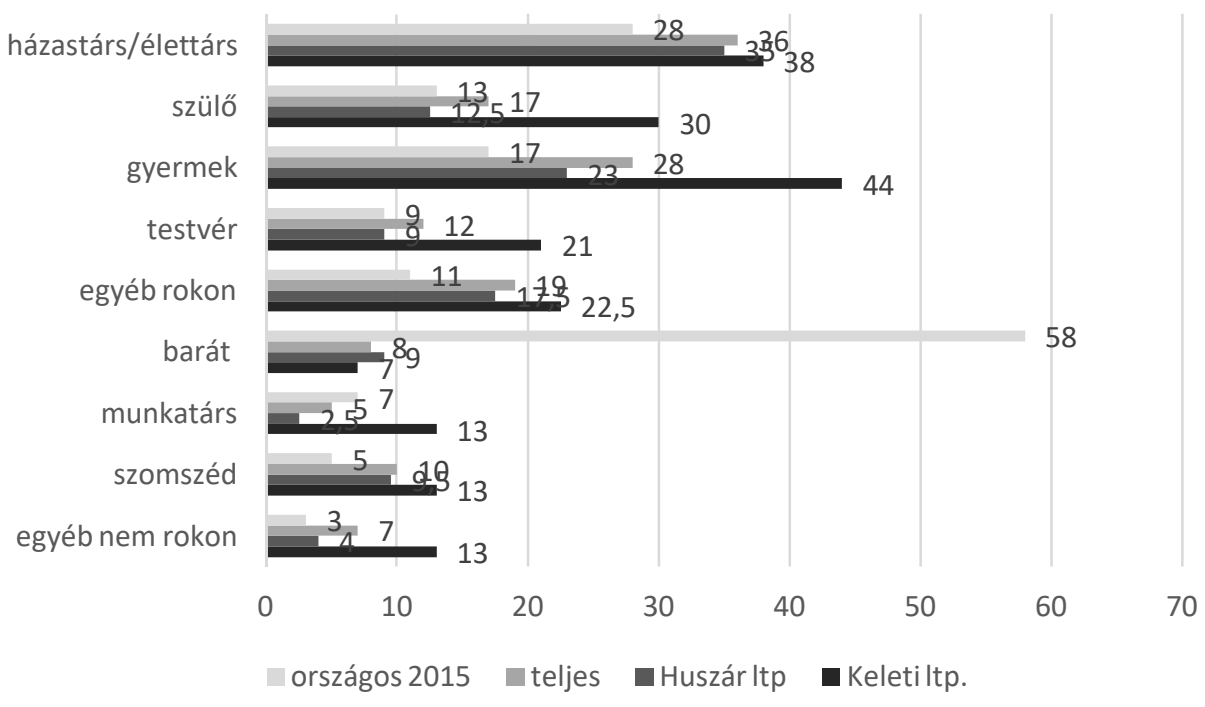

Forrás: Roma lakótelepen élök életminősége, 2019, és Integrációs és dezintegrációs folyamatok a magyar társadalomban címü OTKA kutatás adatfelvétele

1. ábra Az egyes kapcsolattípusok említési aránya a bizalmasok között 
A bizalmasok között felsorolt személyek jelentős részét (92\%) a megkérdezettek több mint egy éve ismerik. A megnevezett személyek 73\%-a az adott telepen él, ahol a megkérdezett. 38,5\%-uk ugyanabban a háztartásban, 15,5\%-uk ugyanabban az utcában, 19\%-uk pedig ugyanazon a telepen, de egy másik utcában. A megnevezett személyek 7\%-a él a telephez közel, 13\%-a a város távolabbi részén, 7\% pedig más városban. A kutatás során megkérdezettek tehát térben nagyon közeli, időben pedig meglehetősen távoli, régi kapcsolatokkal rendelkeznek, ami a bizalmas kapcsolatokat illeti.

Ha a két telepet külön-külön vizsgáljuk, fontos különbségek válnak jól láthatóvá. Míg abban nincs jelentős eltérés a két telepen élők között, hogy bizalmasaik régi, több éve tartó ismeretségek, a bizalmasként megjelölt személyek lakóhelye és etnikai hovatartozása jelentős eltéréseket mutat. A Huszár lakótelepiek által említett bizalmas kapcsolatok sokkal inkább a telepről, ugyanabból a háztartásból, egy másik telepi utcáról, kerülnek ki, míg a Keleti lakótelepen élők által említett bizalmas kapcsolatok ötöde (21\%) a város távolabbi részén él. A más városban élö bizalmasok gyakoribbak a Huszár lakótelepi kérdezettek körében (7,5\% vs. 3\%). Fontos kiemelni a bizalmasként megjelölt személyek etnikai hovatartozását (amelyet a kérdezettek általi besorolás alapján veszünk figyelembe). A Keleti lakótelepen élők által említett bizalmasok lényegesen nagyobb arányban lettek romaként említve, mint a Huszár lakótelepiek körében. (3. táblázat)

A bizalmasként említett személyek etnikai hovatartozása és a lakóhely távolságának besorolása (a város távolabbi részén) következtethetünk arra, hogy a Keleti lakótelepen élőknek a városban élő más roma családokkal van jó, bizalmas kapcsolata. (3. táblázat)

\begin{tabular}{|c|c|c|c|}
\hline & $\begin{array}{l}\text { Teljes telepi } \\
\text { minta }(\%)\end{array}$ & $\begin{array}{c}\text { Huszár lakó- } \\
\text { telep (\%) }\end{array}$ & $\begin{array}{l}\text { Keleti lakóte- } \\
\text { lep }(\%)\end{array}$ \\
\hline \multicolumn{4}{|l|}{$\begin{array}{l}\text { Mióta ismeri a megnevezett } \\
\text { személyt? }\end{array}$} \\
\hline néhány hete & 0,5 & 1 & - \\
\hline néhány hónapja & 1 & 1 & 1 \\
\hline néhány éve & 7 & 7 & 7 \\
\hline régebben & 91,5 & 91 & 92 \\
\hline \multicolumn{4}{|l|}{$\begin{array}{l}\text { Milyen messze lakik a megneve- } \\
\text { zett személy? }\end{array}$} \\
\hline ugyanabban a háztartásban & 39 & 40 & 36 \\
\hline ugyanabban az utcában & 15 & 14,5 & 17 \\
\hline másik utcában a telepen & 19 & 20 & 18 \\
\hline a telephez közel & 7 & 8 & 6 \\
\hline a város távolabbi részén & 13 & 9 & 21 \\
\hline más városban & 6 & 7,5 & 3 \\
\hline egyéb & 1 & 1 & - \\
\hline \multicolumn{4}{|l|}{ A megnevezett személy } \\
\hline roma & 67 & 57 & 83 \\
\hline nem roma & 33 & 43 & 17 \\
\hline
\end{tabular}

Forrás: Forrás: Roma lakótelepen élök életminösége, 2019

3. táblázat A bizalmasként megnevezett személyek jellemzői (\%) 
A támogatásokat tekintve megkérdeztük, hogy a bizalmasként megnevezett személy nyújt-e a megkérdezettnek bizonyos típusú segítséget. Az öt kategória a következő volt: érzelmi, anyagi, szabadidő eltöltés, információ, tanács-útmutatás. (4. táblázat)

A bizalmasként megnevezett személyek $85 \%$-a nyújt a kérdezettnek érzelmi támogatást, 58\%-uk anyagi támogatást, 50\%-ukra lehet számítani szabadidő eltöltésnél, 64\%-uk nyújt információt, 70\%-uk pedig tanácsot és útmutatást. A rangsor tehát a következőképpen alakul: leggyakrabban érzelmi támogatást kapnak a bizalmas kapcsolatoktól a válaszadók, majd tanácsot, útmutatást várhatnak leggyakrabban. Ezt az információnyújtás követi, majd az anyagi támogatás. A bizalmasként megnevezettek fele jelent szabadidős társaságot a megkérdezettek számára.

A bizalmas kapcsolatok által biztosított támogatásokat megvizsgáltuk a két telepen külön-külön. A Huszár lakótelepen élő válaszadók az átlagnál gyakrabban kapnak bizalmas kapcsolataiktól érzelmi és anyagi támogatást, illetve a szabadidős együttlétek is gyakrabban jelennek meg. A Keleti lakótelepen élők számára a bizalmas kapcsolatok leginkább az érzelmi támogatást, tanácsadást, útmutatást, információforrást jelentik, kevésbé az anyagi támogatást és szabadidős tevékenységet.

\begin{tabular}{|l|l|l|l|}
\hline & $\begin{array}{c}\text { Huszár } \\
\text { lakótelep (\%) }\end{array}$ & $\begin{array}{c}\text { Keleti } \\
\text { lakótelep (\%) }\end{array}$ & $\begin{array}{c}\text { Teljes telepi } \\
\text { minta (\%) }\end{array}$ \\
\hline Érzelmi támogatás & 89 & 79 & 85 \\
\hline Tanács, útmutatás & 71 & 69 & 70 \\
\hline Információ nyújtás & 62,5 & 65,5 & 64 \\
\hline Anyagi támogatás & 67,5 & 43 & 58 \\
\hline Szabadidő, szórakozás & 55 & 42,5 & 50 \\
\hline
\end{tabular}

Forrás: Roma lakótelepen élök életminősége, 2019

4. táblázat A bizalmasok által nyújtott támogatásfajták

\section{Barátságok}

A megkérdezettek átlagosan 4,84 baráttal rendelkeznek (Std.dev. 15,354 Min.0 Max.98). Ez jóval magasabb szám, mint a legutóbb (2017-ben) országosan mért, átlag 2,1 barát, viszont kicsivel alacsonyabb a Nyíregyházán 2018-ban mért 5,1-nél (Huszti, 2018). A válaszadók 48\%-a mondta azt, hogy neki nincs egyetlen barátja sem. Ez az arány azonban jóval magasabb, mint az országos (24\%) illetve nyíregyházi (11\%) arány. 1-4 barátja a megkérdezettek 38\%-ának, 5-9 barátja 4\%-nak, tíz vagy attól több barátja minden tizedik válaszadónak van.

Az átlagos barátszámot leginkább az befolyásolja, hogy melyik telepen él a megkérdezett: míg a Keleti lakótelepen élők esetén az átlagos barátszám 9,4 (Std.dev. 20,394) volt, a Huszár lakótelepiek átlagosan 3,4 (Std.dev. 13,106) barátot tudnak maguk körül $(\mathrm{p}=0,008)$. A barátok száma jelentős eltérést mutat a két telep viszonylatában. A Keleti lakótelepen élő megkérdezettek között kevesebben vannak azok, akiknek egyetlen barátja sincs, illetve akik 1-4 baráttal rendelkeznek. A baráthalmozók aránya azonban a Keleti lakótelepen négyszerese a Huszár lakótelepi válaszadókénál és magasabb mind az országos, mind a nyíregyházi adatoknál. (5. táblázat) 


\begin{tabular}{|l|l|l|l|l|l|}
\hline & $\begin{array}{c}\text { Országos } \\
\mathbf{2 0 1 7 *} \\
(\mathbf{\%})\end{array}$ & $\begin{array}{c}\text { NYHP } \\
\mathbf{2 0 1 8} \\
\mathbf{( \% )}\end{array}$ & $\begin{array}{c}\text { Teljes } \\
\text { telepi } \\
\text { minta } \\
\mathbf{( \% )}\end{array}$ & $\begin{array}{c}\text { Huszár } \\
\text { lakótelep } \\
\mathbf{( \% )}\end{array}$ & $\begin{array}{c}\text { Keleti } \\
\text { lakótelep } \\
(\mathbf{\%})\end{array}$ \\
\hline Barátok száma & & & & & \\
0 barát & 24 & 11 & 48 & 49 & 44 \\
1-4 barát & 65 & 54 & 38 & 42 & 24 \\
5-9 barát & 7 & 25 & 4 & 3 & 8 \\
10 vagy több barát & 4 & 10 & 10 & 6 & 24 \\
\hline
\end{tabular}

Forrás: Roma lakótelepen élők életminősége, 2019, Nyíregyháza életminöség 2018

*Psyma Hungary Kft. 2017. októberi lakossági omnibusz kutatása

5. táblázat $\mathrm{A}$ barátok számának megoszlásai a vizsgált mintákon (\%)

Nemek között látunk eltérést a barátok számát tekintve: a férfiak átlagosan 8,4 (Std.dev.23,202) barátot, a nők 3,3-t (Std.dev. 9,963) neveztek meg $(\mathrm{p}=0,016)$. Ha telepenként vizsgáljuk, elmondható, hogy a Huszár lakótelepi férfiaknak átlagosan kevesebb, a Keleti lakótelepieknek viszont jóval magasabb a barátaik száma. Ez a különbség a nők esetében is megfigyelhető: a Huszár lakótelepen élő nők átlagosan 2,4 baráttal, a Keleti lakótelepi nők pedig 6 baráttal rendelkeztek. (6. táblázat)

A megkérdezettek kora is fontos a barátok számát tekintve: a 18-39 éveseknek van a legtöbb barátjuk átlagosan $(6,2)$ és a legidősebb, 60 éves és idősebb válaszadóknak a legkevesebb $(2,3)$. Ha telepenként nézzük, a Huszár lakótelepen élők esetében minden korcsoportban jelentősen kevesebb az átlagos barátszám, míg a Keleti lakótelepen élők esetében lényegesen magasabb, különösen a fiatalok körében. (6. táblázat)

\begin{tabular}{|c|c|c|c|}
\hline & $\begin{array}{c}\text { Huszár } \\
\text { lakótelep }\end{array}$ & $\begin{array}{c}\text { Keleti } \\
\text { lakótelep }\end{array}$ & Teljes telepi minta \\
\hline \multirow[t]{4}{*}{ Barátok száma } & 3,4 & 9,4 & 4,84 \\
\hline & 0,0 & 0,0 & 0,0 \\
\hline & 98,0 & 98 & 98,0 \\
\hline & 13,106 & 20,394 & 15,354 \\
\hline \multirow[t]{2}{*}{ A válaszadó neme: } & 5,9 & 15,0 & 8,4 \\
\hline & 2,4 & 6,0 & 3,3 \\
\hline \multicolumn{4}{|l|}{ A válaszadó kora: } \\
\hline 18-39 évesek & 3,9 & 14,2 & 6,2 \\
\hline 40-59 évesek & 2,5 & 6,5 & 3,5 \\
\hline $\begin{array}{rr}60+ \\
\end{array}$ & 1,0 & 6,4 & 2,3 \\
\hline \multicolumn{4}{|l|}{ A válaszadó iskolai végzettsége } \\
\hline Max. 8 osztály & 3,3 & 8,0 & 4,5 \\
\hline Szakmunkás & 3,5 & 17,3 & 6,3 \\
\hline Érettségi + & 4,1 & - & 4,1 \\
\hline \multicolumn{4}{|l|}{ A válaszadó származása: } \\
\hline Roma & 2,2 & 11,0 & 5,1 \\
\hline Nem roma & 4,0 & 7,6 & 4,7 \\
\hline
\end{tabular}

Forrás: Roma lakótelepen élök életminősége, 2019

6. táblázat A barátok száma és más szociodemográfiai jellemzők 
Jellemző tehát mindkét telepen, hogy a férfiak átlagosan több baráttal rendelkeznek, illetve a 18-39 évesek azok, akik a telepre jellemző átlagtól több baráti kapcsolatról számoltak be a kérdezés során. A szakmunkás végzettséggel rendelkező válaszadók átlagosan közel két baráttal rendelkeznek többel, mint azok, akiknek maximum nyolc általánosuk van. A szakmunkás végzettség a Keleti lakótelepen párosul kiugróan magas barátszámmal. (6. táblázat)

A megkérdezett etnikai identitását és a barátok átlagos számát vizsgálva elmondható, hogy nincs lényeges különbség a magukat romáknak valló megkérdezettek és a magukat magyarnak vallók között (5,1 vs. 4,7). A telepek között azonban itt is különbség van: a Huszár telepen kétszer annyi barátja van azoknak, akik nem romának vallják magukat, a Keleti lakótelepen viszont azoknak van több barátjuk, akik romának vallották magukat. (6. táblázat)

Közel azonos (63 ill. 61\%) a két telepen azok aránya, akiknek nincs barátjuk és magukat magyarnak vallják. A baráthalmozók (10 vagy annál több barátjuk van) a Huszár lakótelepen magukat magyarnak valló válaszadókból kerültek ki (64\%), míg a Keleti lakótelepen inkább a magukat romákként definiálók közül (71\%).

\section{Gyenge kötések}

A gyenge kötések léte vagy nem léte az egyén kapcsolathálózatában a társadalmi beágyazódottságra utal. Jelen kutatásban 30 különböző foglalkozást soroltunk fel, amely kapcsán a kérdezettnek jeleznie kellett, hogy ismer-e olyat, aki az adott foglalkozást képviseli. Minél több foglalkozáshoz tartozót ismer az egyén, annál több társadalmi tőkét tud elérni, mozgósítani adott esetben.

A 7. táblázatban azt foglaltuk össze, hogy a megkérdezettek mennyire ismernek különböző foglalkozású embereket. A táblázat a legismertebb foglalkozás felől halad a kevésbé ismertek felé. Feltüntettük a táblázatban azt is, hogy az adott foglalkozást üző személy, akire a megkérdezett elsősorban gondolt, milyen nemü, hol lakik, illetve, hogy a megkérdezett szerint roma vagy nem roma származású. A kérdés kapcsán felidézett személyek általában férfiak azon foglalkozások esetében, amelyeket inkább a férfi válaszadók említettek, mint például: segédmunkás, szakmunkás, biztonsági őr, sofőr, vállalkozó, parasztgazda, ügyvéd, politikus, mérnök.

\begin{tabular}{|l|l|l|l|l|}
\hline Foglalkozás & Ismer & \multicolumn{3}{|l|}{ Ha ismer ilyet, akkor az adott } \\
személy:
\end{tabular}




\begin{tabular}{|l|l|l|l|l|}
\hline Foglalkozás & Ismer & \multicolumn{3}{|l|}{$\begin{array}{l}\text { Ha ismer ilyet, akkor az adott } \\
\text { személy: }\end{array}$} \\
\hline & $\begin{array}{l}\text { Igen } \\
(\%)\end{array}$ & $\begin{array}{l}\text { Neme } \\
\text { férfi } \\
(\%)\end{array}$ & $\begin{array}{l}\text { Hol lakik? } \\
\text { nem a te- } \\
\text { lepen (\%) }\end{array}$ & $\begin{array}{l}\text { Roma szárma- } \\
\text { zású? nem (\%) }\end{array}$ \\
\hline Védőnő & 53 & 4 & $\mathbf{9 8}$ & $\mathbf{9 9}$ \\
\hline Fodrász & 46 & 16 & 71 & 67 \\
\hline Örzö-védő biztonsági ör & 36,5 & 95 & 76 & 77 \\
\hline Soför & 36 & 85 & 65 & 54 \\
\hline Asszisztens, kórházi ápoló & 32,5 & 9 & $\mathbf{9 5 , 5}$ & $\mathbf{9 3}$ \\
\hline Szociális irodán ügyintézö & 31 & 14 & $\mathbf{9 9}$ & $\mathbf{1 0 0}$ \\
\hline Vállalkozó & 30 & 94 & 80 & 58 \\
\hline Civil szervezet munkatársa & 27 & 22,5 & 91 & 74 \\
\hline Középiskolai tanár & 25,5 & 52 & $\mathbf{9 7}$ & $\mathbf{9 2 , 5}$ \\
\hline Igazgató & 25 & 73,5 & $\mathbf{9 7}$ & $\mathbf{9 8 , 5}$ \\
\hline Önkormányzati képviselö & 24 & 43 & 81,5 & 44 \\
\hline Pincér & 21 & 59 & 71 & 70 \\
\hline Ügyvéd & 15 & 90 & $\mathbf{1 0 0}$ & $\mathbf{9 5}$ \\
\hline Adminisztrátor & 13 & 6 & 94 & 89 \\
\hline Parasztgazda & 11 & 97 & 97 & 79 \\
\hline Butikos & 11 & 10 & 87 & 87 \\
\hline Sebész & 7 & 89,5 & $\mathbf{1 0 0}$ & $\mathbf{9 5}$ \\
\hline Politikus & 7 & 100 & 95 & 75 \\
\hline Mérnök & 5 & 93 & 93 & 93 \\
\hline Újságíró & 5 & 50 & $\mathbf{1 0 0}$ & $\mathbf{1 0 0}$ \\
\hline Belsóépítész & 4 & 67 & 83 & 73 \\
\hline Bankár & 4 & 70 & $\mathbf{1 0 0}$ & $\mathbf{1 0 0}$ \\
\hline Színész & 4 & 60 & 90 & 89 \\
\hline Tudós & 2 & 100 & 60 & 60 \\
\hline
\end{tabular}

Forrás: Roma lakótelepen élők életminösége, 2019

7. táblázat A foglalkozási pozíciógenerátor egyes tételeinek említési gyakorisága, az adott foglalkozású ismerősök néhány jellemzője (\%)

A foglalkozások mentén megjelölt ismerősök (vélt) lakóhelye illetve származása fontos mutatója lehet a makrotársadalmi integrációnak. A nem telepen élő és nem kisebbséghez tartozó ismerősök jelenthetik az úgynevezett bridging (Lin, 2008), hídszerü kötéseket, melyek a telepen élöket kötik össze a nem telepiekkel. A felsorolt foglalkozások közül a következöket betöltő személyek lehetnek fontosak a telepen élök makrotársadalmi integrációja szempontjából (alacsony (10\% alatti) közöttük a telepen élök aránya és magas ( $90 \%$ feletti) a nem romák aránya): gyermekorvos, szociális munkás (családsegítő), védőnő, asszisztens/kórházi ápoló, szociális irodai ügyintéző, középiskola tanár, igazgató, ügyvéd, sebész, mérnök, újságíró, bankár.

A válaszadók leggyakrabban segédmunkást (1.), gyermekorvost (2.), szakmunkást (3.), szociális munkást (4.) és a lakáskezelőnél (NYÍRVV) ügyintézőt (5.) ismernek. Legritkábban belsőépítészt, bankárt, színészt illetve tudóst említettek az ismert foglalkozások között. A 2015-ös országos adatok szerint az emberek legin- 
kább bolti eladót, segédmunkást és sofört ismernek, legkevésbé pedig újságírót, színészt, sebészt, egyetemi oktatót, kutatót (Albert-Dávid, 2016).

Az ismert foglalkozások sorrendjét nézve megállapíthatjuk, hogy a két telepen eltérő gyakorisággal ismernek a különböző foglalkozásokat képviselő személyeket. A Huszár lakótelepi válaszadók leggyakrabban segédmunkást (1.), majd a lakáskezelőnél (NYÍRVV) ügyintézőt (2.), szakmunkást (3.), gyermekorvost (4.) illetve szociális munkást (5.) ismernek. Ezek alapvetően alacsony presztízsü foglalkozások (segédmunkás, szakmunkás), illetve olyan foglalkozások, melyekre a gyermekgondozás illetve a mindennapos ügyek intézése (gyermeknevelés, családdal kapcsolatos támogatások, lakással kapcsolatos ügyintézés) során lehet szükség.

A Keleti lakótelepen élő válaszadók által említett gyakoriság ettől némiképp eltér: leggyakrabban a szociális munkást említik (1.), majd a gyermekorvost (2.), akit a bolti eladó (3.), majd a segédmunkás (4.) és szakmunkás (5.) követ a gyakorisági sorrendben. A lakáskezelő vállalat a Keleti lakótelep szélén van, az ügyintéző említése azonban kevésbé gyakori a Keleti lakótelepiek, mint a Huszár telepiek között.

Pókháló diagramon ábrázolva (2. ábra) jól látható, hogy a felsorolt foglalkozások képviselőjének ismertsége két részre osztható: a diagram jobb oldalán láthatók azok a foglalkozások, melyek képviselői közül leggyakrabban említettek a válaszadók, a bal oldalon pedig azok, ahol elenyésző volt az említett ismerősök aránya. Ez utóbbiak jellemzően a magasabb presztízzsel bíró foglalkozások, mint a tudós, bankár, mérnök, sebész, ügyvéd, újságíró, színész.

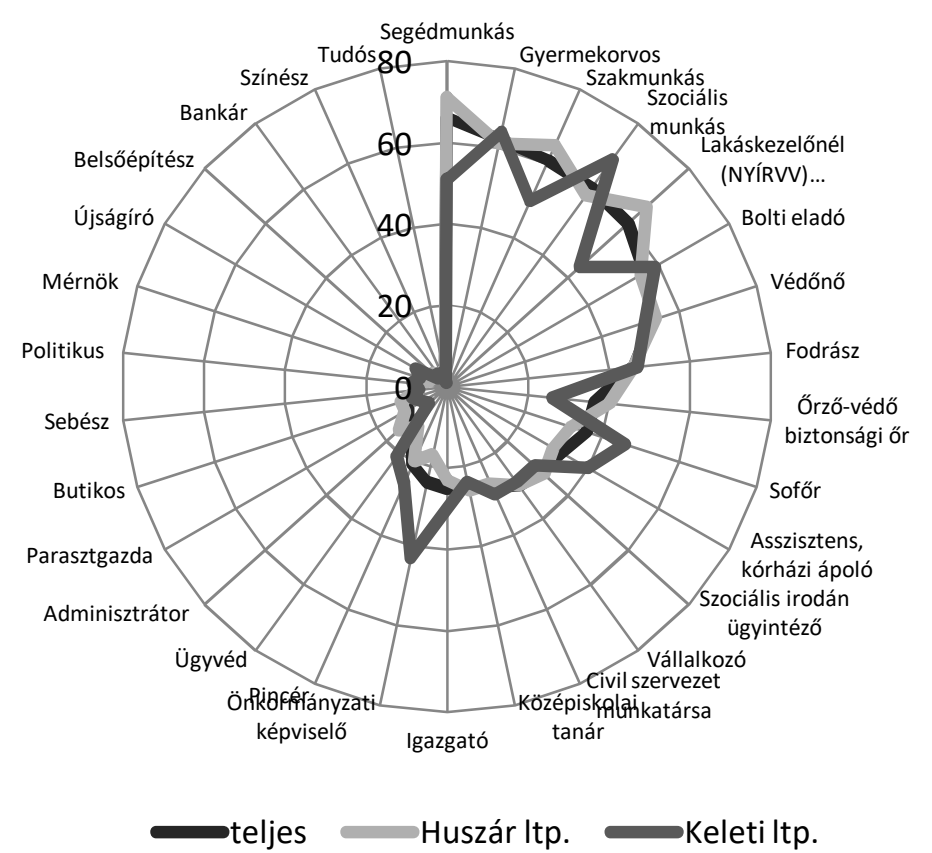

Forrás: Roma lakótelepen élők életminősége, 2019

2. ábra A foglalkozási pozíciógenerátor egyes tételeinek említési gyakorisága (\%) 
A felsorolt 30 foglalkozás közül egyikből sem rendelkezik ismerőssel a válaszadók $7 \%$-a. Ez magasabb, mint az országosan mért $2 \%$.

1-5 vizsgált foglalkozással rendelkező ismerőst a válaszadók 31\% jelölt, 6-9 vizsgált foglalkozással rendelkező ismerőst 23\%-uk, 10-19 vizsgált foglalkozással rendelkező ismerőst 34\%-uk, 20 vagy annál többet a megkérdezettek 5\%-a ismert. A Huszár lakótelepi válaszadók 6,5\%-ának nem volt ismerőse a megadott foglalkozásúak közül, a Keleti lakótelepiek 7\%-a tartozott ide, azaz nincs jelentős különbség a két telep között. A két telepen élő megkérdezettek közel ugyanolyan arányban említettek a különböző foglalkozások közül 1-5 illetve 6-9 ismerőst. A 10 vagy annál több foglalkozás esetén ismeröst jelölök a Keleti lakótelepen voltak valamivel nagyobb arányban (40 vs. 37\%). (8. táblázat)

\begin{tabular}{|l|l|l|l|l|l|}
\hline & $\begin{array}{l}0 \\
\text { foglalkozás } \\
(\%)\end{array}$ & $\begin{array}{l}1-5 \\
\text { foglalkozás } \\
(\%)\end{array}$ & $\begin{array}{l}6-9 \\
\text { foglalkozás } \\
(\%)\end{array}$ & $\begin{array}{l}10-19 \\
\text { foglalkozás } \\
(\%)\end{array}$ & $\begin{array}{l}20+ \\
\text { foglalkozás } \\
(\%)\end{array}$ \\
\hline $\begin{array}{l}\text { Huszár } \\
\text { lakótelep }\end{array}$ & 6,5 & 31 & 22 & 35 & 5 \\
\hline Keleti lakótelep & 7 & 31 & 24 & 30 & 7 \\
\hline $\begin{array}{l}\text { Megkérdezett } \\
\text { neme }\end{array}$ & & & & & \\
Férfi & 13 & 29 & 18 & 32 & 8 \\
Nő & 4 & 32 & 25 & 35 & 4 \\
\hline Megkérdezett & & & & & \\
kora & 3,5 & 26 & 23 & 42 & 6 \\
$18-39$ & 7 & 31,5 & 26 & 29 & 6 \\
$40-59$ & 13 & 46 & 15 & 23 & 3 \\
$60+$ & & &
\end{tabular}

Forrás: Roma lakótelepen élök életminösége, 2019

8. táblázat A foglalkozási pozíciógenerátorok említéseinek megoszlása az almintákon illetve a megkérdezettek nemi és életkori megoszlása az adott számú foglalkozást említők csoportjai szerint, \%

A megkérdezettek neme meghatározó: a férfiak közül lényegesen többen vannak azok, akik nem tudtak felsorolni senkit a megadott 30 foglalkozás közül. A nők aránya magasabb az 1-5, a 6-9 illetve a 10-19 vizsgált foglalkozású ismerőst megnevezők között. A férfiak aránya azonban magasabb azok között, akik legalább 20 foglalkozáshoz is tudtak ismerőst megjelölni.

A felsorolt foglalkozások közül a 60 éves és idősebb válaszadóknak volt legkevésbé ismerősük (13\%), ez a korcsoport leginkább 1-5 vizsgált foglalkozású ismerőssel rendelkezett maximum. A legtöbb foglalkozású ismerőst (10 vagy annál több) a 18-39 évesek nevezték meg.

A megkérdezettek nemét vizsgálva láthatjuk, hogy a nők jellemzően olyan foglalkozású embereket ismernek gyakrabban, mint a gyermekorvos, szociális munkás, lakáskezelő ügyintézője, bolti eladó, védőnő, fodrász, ápoló, szociális irodán ügyintéző, civil szervezet munkatársa, tanár, igazgató, butikos. Ezek a foglalkozások elsősorban a gyermekekhez, a családhoz, a lakáshoz, a mindennapos étkezésekhez, meg- 
jelenéshez köthetők. A férfiaknak inkább szakmunkásból, segédmunkásból, vállalkozóból, biztonsági őrből, sofőrből, pincérből van több ismerőse. (3. ábra)

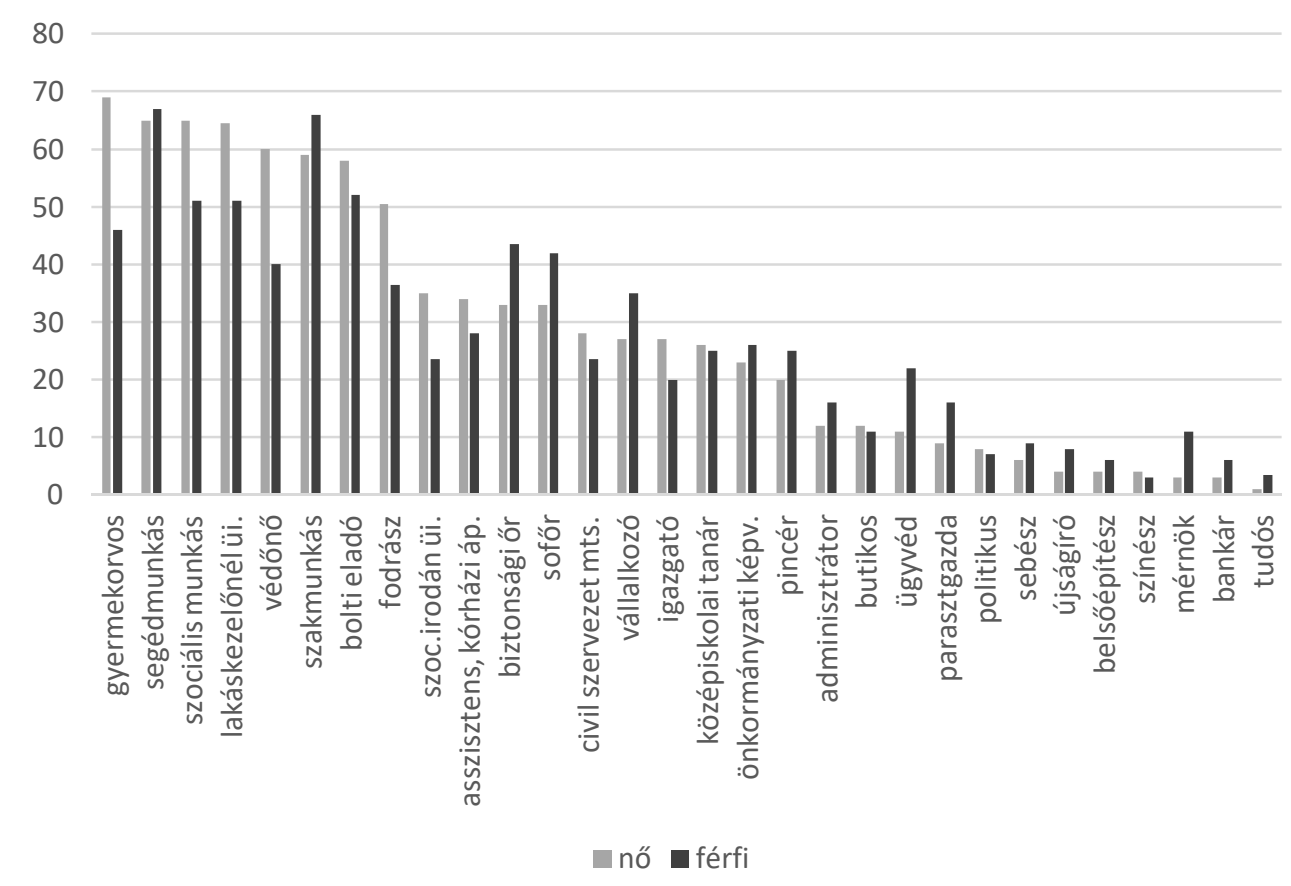

Forrás: Roma lakótelepen élők életminősége, 2019

3. ábra A foglalkozási pozíciógenerátor egyes tételeinek említési gyakorisága nemi bontásban $(\%)$

A korcsoportokat vizsgálva is különbségek tárhatók fel. A 4. ábra a leggyakrabban említett foglalkozásokat mutatja be három korcsoport szerint. A szakmunkások kivételével minden gyakran említett foglalkozás esetén a legfiatalabb korosztály tünik ki, nekik van a leginkább kapcsolatuk az adott foglalkozás képviselőivel.

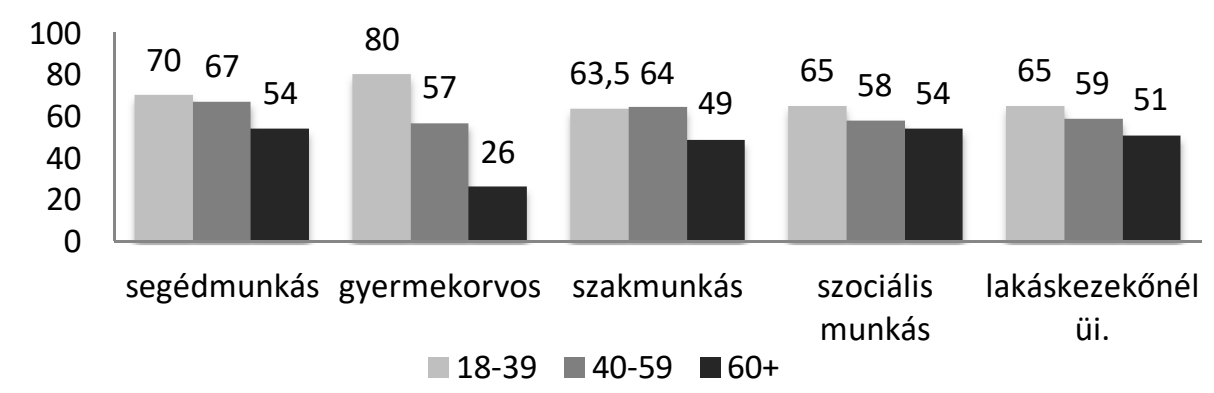

Forrás: Roma lakótelepen élők életminősége, 2019

4. ábra A foglalkozási pozíciógenerátor egyes tételeinek említési gyakorisága életkor szerinti bontásban $(\%)$ 


\section{Összefoglalás}

Az általunk vizsgált telepeken, főleg a Huszár lakótelepen alacsonyabb a bizalmas kapcsolatok átlagos száma, mint az országos átlag (1,48 vs. 2,19) és magasabb azok aránya, akiknek egyáltalán nincsenek bizalmas kapcsolataik (14\% vs. 6,5\%). Jellemző, hogy a megkérdezettek térben nagyon közeli, időben pedig meglehetősen távoli, régi kapcsolatokkal rendelkeznek. A válaszadók bizalmas kapcsolathálózatában leginkább rokoni kapcsolatokat láthatunk. A kapcsolathálózat összetétele szempontjából a két telep között lényeges eltérés van. A bizalmas kapcsolatokat tekintve a megkérdezettek kapcsolatrendszere homofil, azaz a saját magukhoz hasonló szociodemográfiai ismérvekkel jellemezhető mások találhatók meg benne. A Huszár lakótelepen élő válaszadók az átlagnál gyakrabban kapnak bizalmas kapcsolataiktól érzelmi és anyagi támogatást, illetve a szabadidős együttlétek is gyakrabban jelennek meg. A Keleti lakótelepen élök számára a bizalmas kapcsolatok leginkább az érzelmi támogatást, tanácsadást, útmutatást, információforrást jelentik, kevésbé az anyagi támogatást és szabadidős tevékenységet.

A Keleti lakótelepen élőknek átlagosan több a bizalmas kapcsolata, magasabb közöttük a sok baráttal rendelkezők aránya. Az átlagos barátszám a Keleti lakótelepen háromszorosa a Huszár lakótelepi válaszadókénak.

A bizalmasként említett személyek etnikai hovatartozása és a lakóhely távolságának besorolása alapján arra következtethetünk, hogy a Keleti lakótelepen élőknek a városban élő más roma családokkal van jó, bizalmas kapcsolata.

A barátok száma és a bizalmasok száma között pozitív összefüggés van: minél több baráttal rendelkezik a megkérdezett, annál több bizalmast tudott megnevezni.

A felsorolt 30 foglalkozás közül egyikből sem rendelkezik ismerőssel a válaszadók 7\%-a. Ez magasabb, mint az országosan mért 2\%. A férfiak közül lényegesen többen vannak azok, akik nem tudtak felsorolni senkit a megadott 30 foglalkozás közül. Az ismert foglalkozások sorrendjét nézve megállapítható, hogy a két telepen eltérő gyakorisággal ismernek a különböző foglalkozásokat képviselő személyeket.

\section{Felhasznált irodalmak jegyzéke}

1. Albert, F. - Dávid, B. (2016): A magyarországi kapcsolathálózati struktúrák jellemzői 2015-ben. Socio.hu Társadalomtudományi Szemle, 3:22-47. doi: 10.18030/socio.hu.2016.3.22

2. Hüse L., Takács P., Huszti É. (szerk.) (2015): A Nyíregyházi járás életminősége 2015. Acta Medicinae et Sociologica Vol. 6. No. 18-19.

3. Balogh E. (2019): Iskolázottsági helyzetkép - Nyíregyházán telepi körülmények között élők körében. Acta Medicina et Sociologica Vol 10. No.29. 55-69.

4. Fábián G., Patyán L., Huszti É. (szerk.) (2012): Életminőség Nyíregyházán 2008-2010. Acta Medicinae et Sociologica Vol. 3. No. 3.

5. Huszti É., Patyán L., Fábián G. (szerk.) (2014): Életminőség Nyíregyházán 2012. Acta Medicinae et Sociologica Vol. 5. No. 12-13. 
6. Fábián G., Huszti É., Hüse L., Takács P. (2018): Az életminőség Nyíregyházán - A nagymintás társadalomkutatás első négy hulláma a megyeszékhelyen. Szabolcs-Szatmár-Beregi Szemle, 2018/3 p. 83-102.

7. Fábián G., Takács P. (2019): Jövedelmi helyzet, jövedelmi viszonyok a telepi lakosok körében. Acta Medicina et Sociologica Vol 10. No.29. 45-54.

8. Granovetter, M. (1973) The Strength of Weak Ties. American Journal of Sociology, 78:1360-1380.

9. Huszti, É. (2018): Társas kapcsolatok Nyíregyházán 2008-2018. Acta Mediciane et Sociologica Vol.9. No. 27: 110-124. DOI: $10.19055 / \mathrm{ams} .2018 .9 / 27 / 8$

10. Lin, N. - Dumin, M. (1986) Access to Occupations through Social Ties. Social Networks, 8(4), 365-85.

11. McCallister, L., Fischer, C.S. (1978). A procedure for surveying personal networks. Sociological Methods and Research, 7:131-148

12. Rahman T. - Mittelhammer R.C. - Wandschneider P. 2005: Measuring the Quality of Life across Countries. Research Paper No. 06.

13. Takács P., Huszti É. (2019): A nyíregyházi Huszár- és Keleti lakótelepi vizsgálatok - a kutatás módszertana és a minta néhány alapvető jellemzője. Acta Medicina et Sociologica Vol 10. No.29. 8-18. 